\title{
Poly (hydroxyethyl methacrylate-glycidyl methacrylate) films modified with different functional groups: In vitro interactions with platelets and rat stem cells
}

\author{
Gulay Bayramoglu ${ }^{\mathrm{a}, *}$, Verda Bitirim ${ }^{\mathrm{b}}$, Yagmur Tunali ${ }^{\mathrm{c}}$, Mehmet Yakup Arica a ${ }^{\mathrm{a}}$, Kamil Can Akcali b, ** \\ a Biochemical Processing and Biomaterial Research Laboratory, Faculty of Sciences, Gazi University, 06500-Teknikokullar-Ankara, Turkey \\ ${ }^{\mathrm{b}}$ Laboratory of Stem Cell Research, Department of Molecular Biology and Genetics, Faculty Science, Bilkent University, 06800 Bilkent-Ankara, Turkey \\ c Department of Pharmaceutical Microbiology, Faculty Pharmacy, Anadolu University, Yunus Emre Campus, Eskisehir, Turkey
}

\section{A R T I C L E I N F O}

\section{Article history:}

Received 8 March 2012

Received in revised form 3 September 2012

Accepted 1 November 2012

Available online 10 November 2012

\section{Keywords:}

Hydrogels

biocompatible polymers

contact angle

blood cell adhesion

hemolysis

rat mesenchymal stem cells

\begin{abstract}
A B S T R A C T
Copolymerization of 2-hydroxyethylmethacrylate (HEMA) with glycidylmethacrylate (GMA) in the presence of $\alpha$ - $\alpha^{\prime}$-azoisobisbutyronitrile (AIBN) resulted in the formation of hydrogel films carrying reactive epoxy groups. Thirteen kinds of different molecules with pendant $-\mathrm{NH}_{2}$ group were used for modifications of the $\mathrm{p}$ (HEMA-GMA) films. The $-\mathrm{NH}_{2}$ group served as anchor binding site for immobilization of functional groups on the hydrogel film via direct epoxy ring opening reaction. The modified hydrogel films were characterized by FTIR, and contact angle studies. In addition, mechanical properties of the hydrogel films were studied, and modified hydrogel films showed improved mechanical properties compared with the non-modified film, but they are less elastic than the non-modified film. The biological activities of these films such as platelet adhesion, red blood cells hemolysis, and swelling behavior were studied. The effect of modified hydrogel films, including $-\mathrm{NH}_{2}$, (using different aliphatic $-\mathrm{CH}_{2}$ chain lengths) $-\mathrm{CH}_{3},-\mathrm{SO}_{3} \mathrm{H}$, aromatic groups with substituted $-\mathrm{OH}$ and $-\mathrm{COOH}$ groups, and amino acids were also investigated on the adhesion, morphology and survival of rat mesenchymal stem cells (MSCs). The MTT colorimetric assay reveals that the p(HEMA-GMA)-GA-AB, $\mathrm{p}$ (HEMA-GMA)-GA-Phe, $\mathrm{p}$ (HEMA-GMA)-GA-Trp, p(HEMA-GMA)-GA-Glu formulations have an excellent biocompatibility to promote the cell adhesion and growth. We anticipate that the fabricated p(HEMA-GMA) based hydrogel films with controllable surface chemistry and good stable swelling ratio may find extensive applications in future development of tissue engineering scaffold materials, and in various biotechnological areas.
\end{abstract}

(c) 2012 Elsevier B.V. All rights reserved.

\section{Introduction}

Hydrogels are polymeric network constructs possessing an inherent water absorbing property, and therefore, they swell in aqueous media, but do not dissolve. The importance of hydrogels has steadily increased in recent years, and the number of polymer applications in tissue engineering continues to grow. Their soft and elastic nature makes them suitable for various biomedical and biotechnological applications. The properties of hydrogels such as the functional groups, chemical composition, hydrophilic-hydrophobic balance, surface morphology, and presence of adherent proteins are essential for the regulation of cellular interactions. Therefore, the performance of a hydrogel material relies highly upon the properties of the boundaries in tissue engineering applications because the interactions between the hydrogel materials and environments occur mainly on its surfaces [1-4]. The hydroxyethyl methacrylate (pHEMA) hydrogel possesses good biocompatibility as evidenced by its large scale use in biomedical and biotechnological

\footnotetext{
* Corresponding author. Tel.: +90 3122021142 .

** Corresponding author. Tel.: +90 5353067509 .

E-mail address: g_bayramoglu@hotmail.com (G. Bayramoglu).
}

applications such as contact lenses, drug delivery systems, and soft tissue prosthesis [5-9]. On the other hand, it lacks functional groups to which biological molecules can easily be attached. Therefore, formation of functional polymers by implementing small-molecule organic chemistry reactions to homo-polymers has attracted great attention lately due to an increasing number of novel potential applications. This post-polymerization modification approach circumvents a number of problems associated with direct polymer synthesis and enables the creation of polymeric systems that are difficult if not impossible to produce otherwise [10]. Several post-polymerization modification approaches have been developed to improve the potential application of the pHEMA hydrogel in the field of biomedical fields [11]. Among them, grafting of phosphorylcholine containing moieties [12] or incorporation of poly(ethylene oxide) chains to the pHEMA back-bones have been reported to reduce protein fouling [8]. In addition, pHEMA inherently exhibits low protein adsorption and, consequently, less cell adhesion [8]. In an attempt to promote cell adhesion, several methods were used to modify pHEMA based hydrogel. Information on the effect of surface chemical composition, especially surface charge, Lewis acid/ base donors, and hydrophilic/hydrophobic balance, on stem cells adhesion and differentiation function is very limited. Information on the 
effect of surface chemical composition, especially surface charge, Lewis acid/base donors, and hydrophilic/hydrophobic balance, on MSC adhesion and differentiation is very limited. MSCs not only have potential to differentiate into tissue-specific cell types [13-15], but also lack immunogenicity and ethical problems [16]. Thus, MSCs emerge as an important player of cellular-based therapies and new approaches are required to increase the viability and functionality of MSCs. For post-polymer surface modifications, reactive co-monomers, typically containing epoxy groups are generally used for single step post polymerization techniques $[12,17,18]$.

Several studies have been carried out to reveal the effect of functional groups of support on cell adhesion, guidance and proliferation. Adhesion, proliferation, viability and function of anchorage dependent cells were shown to be highly related of the surface properties of the substrate biomaterials used [19-23]. Polymer modifications can be used to induce cell responses, in particular $-\mathrm{CH}_{3}$ and $-\mathrm{NH}_{2}$ have been shown to have a potential in enhancing the ability of a material to support mesenchymal stem cell adhesion and differentiation. In addition, hydrogel with a high number pendant $-\mathrm{NH}_{2}$ groups content makes it more cell interactive than those of $-\mathrm{OH}$ and $-\mathrm{COOH}$ groups due to the presence of large number negative electrostatic binding sides of cells surfaces [19-21].

Acrylate based hydrogels have been received more interests on the broad biomedical applications due to their high water content, mechanical and biological properties, including strength, toughness, elasticity, biocompatibility, and easy chemical modification to suit the applications [24,25]. Therefore, preparation of acrylate based hydrogels using various acrylic monomers is of great importance in biomedical applications as it paves the way for the preparation of novel biomaterials with improved mechanical properties [26]. As reported earlier, physical features of microenvironments such as matrix elasticity can clearly influence cell morphology and cell phenotype [27-29]. Cells grown on gels that mimic the elasticity of tissue reveal a significant influence of matrix elasticity on adhesion, cytoskeletal organization, and even the differentiation of human adult derived stem cells. Cellular forces and feedback are keys to how cells feel their mechanical microenvironment, but detailed molecular mechanisms are still being elucidated [30].

To address this question, thirteen kinds of functional groups were created on the $\mathrm{p}$ (HEMA-GMA) hydrogel (i.e., $-\mathrm{NH}_{2},-\mathrm{CH}_{3},-\mathrm{OH}$, $\mathrm{COOH},-\mathrm{SO}_{3} \mathrm{H}$, and L-histidine, L-arginine, L-phenylalanine, L-glutamic acid and L-tryptophan). Glycidylmethacrylate was used for direct coupling of the ligand molecules carrying pendant amino groups. The $-\mathrm{NH}_{2}$ group served as anchor binding site for immobilization of selected ligand on the $\mathrm{p}$ (HEMA-GMA) hydrogel films via direct epoxy ring opening reaction. The properties of the modified hydrogel films were characterized by analytical and biochemical methods. The effects of surface properties of the modified pHEMA based hydrogel on the rat bone marrow derived MSCs adhesion and survival have been evaluated.

\section{Materials and methods}

\subsection{Materials}

Glycidylmethacrylate (GMA), 2-hydroxylethyl methacrylate (HEMA), and $\alpha$ - $\alpha^{\prime}$-azoisobisbutyronitrile (AIBN) were obtained from Fluka AG (Switzerland), and the monomers distilled under reduced pressure in the presence of hydroquinone and stored at $4{ }^{\circ} \mathrm{C}$ until use. L-histidine (His), L-arginine (Arg), L-phenylalanine (Phe), L-glutamic acid (Glu), L-tryptophan (Trp), 4-aminobenzoic acid (AB), 4-hydroxyl aniline (HANI), ammonia (A), ethylene diamine (EDA), hexamethylene diamine (HMDA) and hexylamine (HA) were obtained from Sigma-Aldrich Chem. $\mathrm{GmbH}$ (Germany). Human serum albumin and fibrinogen were supplied from Sigma-Aldrich and used as received. Cell Proliferation assays Kit I (MTT) was obtained from Roche Diagnostics GmbH (Mannheim,
Germany). All other chemicals were of analytical grade and were purchased from Merck AG (Darmstadt, Germany).

For the preparation of phosphate buffer $\mathrm{pH} 7.0,1.20 \mathrm{~g}$ of sodium dihydrogen phosphate and $0.885 \mathrm{~g}$ disodium hydrogen phosphate were dissolved in a $1.0 \mathrm{~L}$ volumetric flask containing about $0.95 \mathrm{~L}$ of distilled water. The $\mathrm{pH}$ of solution was adjusted to 7.0 using $0.1 \mathrm{M}$ $\mathrm{NaOH}$ and/or $0.1 \mathrm{M} \mathrm{HCl}$, and then the volume of flask was completed to $1.0 \mathrm{~L}$ with distilled water. Phosphate buffer at $\mathrm{pH} 8.0$ was prepared by mixing $6.81 \mathrm{~g}$ of potassium dihydrogen phosphate in $0.5 \mathrm{~L}$ distilled with $467 \mathrm{~mL}$ of $0.10 \mathrm{M} \mathrm{NaOH}$ in $1.0 \mathrm{~L}$ volumetric flask the $\mathrm{pH}$ of solution was adjusted to 8.0 and completed to $1.0 \mathrm{~L}$ with distilled water as described above.

\subsection{Preparation of poly(2-hydroxyethyl methacrylate- glycidylmethacrylate) films}

The poly(2-hydroxyethyl methacrylate-glycidylmethacrylate), $\mathrm{p}$ (HEMA-GMA), hydrogel in the film form was prepared by UV-initiated photo-polymerization (Fig. 1). Glycidylmethacrylate (1.5 mL or $11.40 \mathrm{mmol}), 2$-hydroxyethyl methacrylate $(1.5 \mathrm{~mL}$ or $12.37 \mathrm{mmol}$ ), AIBN (20 mg) as polymerization initiator and isopropyl alcohol $(1.1 \mathrm{~mL})$ as a monomer diluent were mixed with distilled water $(1.9 \mathrm{~mL})$. The resulting mixture was mixed and equilibrated at $25{ }^{\circ} \mathrm{C}$ for $15 \mathrm{~min}$ in a thermo-stated water bath. The polymer mixture was flushed with nitrogen for about 5 min before polymerization step. During the polymerization process purified nitrogen gas was used to create a nitrogen atmosphere in the polymerization system. The polymerization was carried out in a round glass mould (diameter: $9.0 \mathrm{~cm}$ ) at $25^{\circ} \mathrm{C}$ for $1 \mathrm{~h}$. After polymerization, the p(HEMA-GMA) films were washed several times with distilled water and cut into circular pieces (diameter: $1.0 \mathrm{~cm}$ ) with a perforator.

\subsection{Modification of $p(H E M A-G M A)$ films}

The free amino groups on the $\mathrm{p}$ (HEMA-GMA) films were created by the ring opening reactions of the epoxy groups of the GMA units of the films with ammonia, ethylene diamine (EDA), and/or hexamethylene diamine (HMDA) and/or hexylamine (HA). The p(HEMA-GMA) films $(5.0 \mathrm{~g})$ were placed in a reactor containing, ammonia $(50 \mathrm{~mL}, 0.5 \mathrm{M})$, ethylene diamine $(50 \mathrm{~mL}, 0.5 \mathrm{M})$ or hexamethylene diamine $(50 \mathrm{~mL}$, $0.5 \mathrm{M})$ or hexylamine $(500.5 \mathrm{M})$ solutions, and the reactions were carried out at $\mathrm{pH} 10.0$ and at $65^{\circ} \mathrm{C}$. The reactor was stirred magnetically for $5 \mathrm{~h}$. After the reaction, the amino modified $\mathrm{p}$ (HEMA-GMA) films were washed with distilled water. The ammonia, EDA, HMDA or HA attached films are called p(HEMA-GMA)-A p(HEMA-GMA)-EDA, $\mathrm{p}$ (HEMA-GMA)-HMDA and $\mathrm{p}$ (HEMA-GMA)-HA films, respectively.

The epoxy groups of the $\mathrm{p}$ (HEMA-GMA) films were hydrolyzed in to diol groups using $\mathrm{H}_{2} \mathrm{SO}_{4}$ as reported previously [31]. The hydrolysis reaction was carried out at $50{ }^{\circ} \mathrm{C}$ for $2 \mathrm{~h}$, while continuously stirring the medium. This film was identified as p(HEMA-GMA)-OH. The epoxy groups of the $\mathrm{p}$ (HEMA-GMA) films were sulfonated using $\mathrm{Na}_{2} \mathrm{SO}_{3}$ in acid/alcohol/water mixture as previously reported [31]. The sulfonation reaction was carried out at $50{ }^{\circ} \mathrm{C}$ for $2 \mathrm{~h}$, while continuously stirring the medium. This film was identified as p(HEMA-GMA)-S.

The aminated films (5.0 g) (i.e., p(HEMA-GMA)-A) were equilibrated in phosphate buffer $(20 \mathrm{~mL}, 50 \mathrm{mM}, \mathrm{pH} 8.0)$ for $6 \mathrm{~h}$, and transferred to the same fresh medium containing glutaraldehyde $(50 \mathrm{~mL}$, $0.5 \%(\mathrm{v} / \mathrm{v}))$. The activation reaction was carried out at $25^{\circ} \mathrm{C}$ for $6 \mathrm{~h}$, while continuously stirring the medium. After the reaction period, the excess glutaraldehyde was removed, and washed with distilled water, acetic acid $(0.1 \mathrm{M}, 200 \mathrm{~mL})$ and phosphate buffer solution (0.1 M, pH 7.0). The resulting p(HEMA-GMA)-GA films were used for attachment of various ligands. The p(HEMA-GMA)-GA films were swollen in phosphate buffer $(0.1 \mathrm{M}, \mathrm{pH} 7.0)$ for $4 \mathrm{~h}$, and were then transferred to the ligand solutions (i.e., L-histidine, L-arginine, 
<smiles>C=C(C)C(=O)OCCO</smiles><smiles>C=C(C)C(=O)OCC1CO1</smiles>

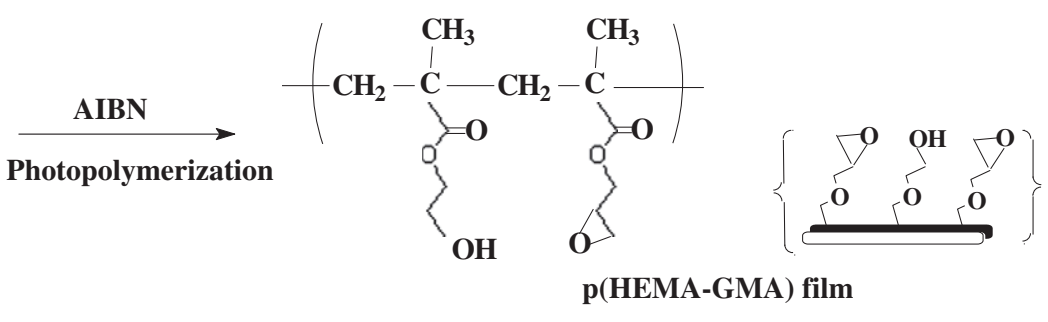

Fig. 1. Chemistry of the preparation of p(HEMA-GMA) films.
L-phenylalanine, L-glutamic acid, L-tryptophan, 4-aminobenzoic acid and 4-hydroxyaniline) $(2.0 \mathrm{mg} / \mathrm{mL}$ each ligand, or $50 \mathrm{mg}$ in $25 \mathrm{~mL}$ phosphate buffer solution). The coupling reactions of the ligands on the glutaraldehyde activated films were carried out at $22{ }^{\circ} \mathrm{C}$ in a shaking water bath for $6 \mathrm{~h}$. After modification reaction, the physically bound ligand was removed from hydrogel sample by a sequential washing. The hydrogel samples were incubated in saline solution $(50 \mathrm{~mL}, 1.0 \mathrm{M})$ for $8 \mathrm{~h}$ at $25^{\circ} \mathrm{C}$ by shaking gently, then hydrogel samples were transferred in phosphate buffer $(100 \mathrm{~mL}, 0.1 \mathrm{M}, \mathrm{pH} 7.0)$, and washed for $4 \mathrm{~h}$ as described above. The different ligands attached films were identified as $\mathrm{p}$ (HEMA-GMA)-GA-His, p(HEMA-GMA)GA-Arg, p(HEMA-GMA)-GA-PhA, p(HEMA-GMA)-GA-Glu, p(HEMAGMA)-GA-Try, p(HEMA-GMA)-GA-AB and p(HEMA-GMA)-GA-HANI, respectively. Each of them was stored at $4{ }^{\circ} \mathrm{C}$ in fresh buffer until use.

\subsection{Characterization studies}

Fourier transform infrared (FTIR) spectra were carried on a spectrophotometer (Mattson 8000 FTIR, England) at room temperature. The samples were prepared in pellet form using spectroscopic grade $\mathrm{KBr}$. Dry $\mathrm{KBr}$ (about $550 \mathrm{mg}$ ) were mixed with $50 \mathrm{mg}$ samples and grinded together in a mortar with pestle. The mixture was then split into three $200 \mathrm{mg}$ aliquots to make three transparent $\mathrm{KBr}$ pellets under vacuum, and $10 \mathrm{~K}$ psi pressure for $10 \mathrm{~min}$.

The water content of the hydrogel films was determined at $25{ }^{\circ} \mathrm{C}$ using a gravimetric method. The pre-weighed dry films were allowed to soak in distilled water for $48 \mathrm{~h}$, swollen film were weighed after removing the excess water, dried in vacuum oven at $60{ }^{\circ} \mathrm{C}$ for $24 \mathrm{~h}$ until constant weight. The swelling properties of the hydrogel networks were determined at three different $\mathrm{pH}$ values in either phthalate buffer $(50 \mathrm{mM}, \mathrm{pH} 2.0)$, phosphate buffer $(50 \mathrm{mM}, \mathrm{pH}$ 7.4) and carbonate buffer ( $50 \mathrm{mM}, \mathrm{pH} 9.0$ ), and each buffer solution was prepared in physiological salt solution $(0.85 \% \mathrm{NaCl})$. The dried films were transferred in above corresponding buffer solution, and the following equation was used to determine the swelling ratio of the hydrogel films at three different $\mathrm{pH}$ values:

Swelling content $(\%)=\left[\left(W_{s}-W_{d}\right) / W_{d}\right] \times 100$

where $W_{s}$ and $W_{d}$ are the weights of swollen and dry film, respectively.

The amount of available functional epoxy group content of the films was determined by pyridine- $\mathrm{HCl}$ method as described previously [31]. The amino group's contents of the aminated, ethylenediamine or hexamethylene diamine attached film samples were determined by potentiometric titration. The film samples about $0.2 \mathrm{~g}$ was transferred in $\mathrm{HCl}$ solution $(0.1 \mathrm{M}, 10 \mathrm{~mL})$ and it was then incubated in a shaking water-bath at $35{ }^{\circ} \mathrm{C}$ for $6 \mathrm{~h}$. After this reaction period, the final $\mathrm{HCl}$ concentration in the solution was determined by a potentiometric titration with $50 \mathrm{mM} \mathrm{NaOH}$ solution. The amount of carboxyl groups of the film samples was determined by potentiometric titration. The films samples $(0.2 \mathrm{~g})$ were allowed at room temperature for $24.0 \mathrm{~h}$ in purified water $(10 \mathrm{~mL})$. Then, sodium hydroxyl solution $(0.5 \mathrm{M}$, $10.0 \mathrm{~mL}$ ) was added to the mixture and shaken for $1.0 \mathrm{~h}$. At the end of this period, the films removed and assayed by titration with $0.1 \mathrm{M}$ $\mathrm{HCl}$ solution. The sulfonic acid group content of the modified film was measured by titration against a standard potassium hydroxide solution $(0.1 \mathrm{~N})$ using phenolphthalein as an indicator. In addition, the amount of immobilized ligands on the $\mathrm{p}$ (HEMA-GMA)-GA films were also determined by measuring the absorbance of the reaction solution before and after adsorption tests of L-histidine, L-arginine, L-phenylalanine, L-glutamic acid, L-tryptophan, 4-aminobenzoic acid or 4-hydroxyaniline at between 220 and $310 \mathrm{~nm}$ by using a double beam UV/Vis spectrophotometer (PG Instrument Ltd., Model T80+; PRC). A calibration curve constructed with each ligand solution of known concentration was used in the calculation of ligand in the solutions.

\subsection{Contact angles studies}

The sessile drop was formed by depositing the liquid from the above using a manual micro-syringe on the membrane surface. Both, the left and right contact angles and drop dimension parameters were automatically calculated from the digitalized image at $25^{\circ} \mathrm{C}$. The contact angles for both sides of each drop were measured as a function of time $5 \mathrm{~s}$ intervals beginning at the instant contact that was made between the liquid and the substrate. The measurements were the average of 5 contact angles at least operated on three hydrogel film samples. The free surface energy parameters of the all film formulation were calculated using the contact angle data of the probe liquids. The results are analyzed according to acid-base method [32,33]. In this method, the contact angles against at least three liquids with known values of $\gamma^{\mathrm{LW}}$, $\gamma^{+}$and $\gamma^{-}$are measured and the superscripts (LW), $(+)$and $(-)$refers to dispersive, Lewis acid and base components, respectively. The values for each experiment are put into the following equation:

$(1+\cos \theta) \gamma_{\mathrm{l}}=2\left[\left(\gamma_{\mathrm{s}}^{\mathrm{LW}} \times \gamma_{\mathrm{l}}^{\mathrm{LW}}\right)^{1 / 2}+\left({\gamma_{\mathrm{s}}}^{+} \times \gamma_{\mathrm{l}}^{-}\right)^{1 / 2}+\left(\gamma_{\mathrm{s}}^{-} \times \gamma_{\mathrm{l}}^{+}\right)^{1 / 2}\right]$

The (s) and (1) refers to solid and liquid phases, respectively. The total surface energy $\gamma^{\mathrm{TOT}}$ is regarded as the sum of Lifschitz-van der Waals and the Lewis acid and base components.

$\gamma^{\mathrm{TOT}}=\gamma^{\mathrm{LW}}+\gamma^{\mathrm{AB}}$

where $\gamma^{\mathrm{LW}}$ designated Lifschitz-van der Waals interaction, reflecting the long-range interactions (including the dispersive interaction, the dipole-dipole interaction, and dipole-induced dipole interaction, which is dominated by the dispersion), was calculated from the measured diiodomethane contact angles, and $\gamma^{\mathrm{AB}}$ designated such acid-base interactions as hydrogen bonding, and $\gamma^{+}$and $\gamma^{-}$refer to proton and electron donating character, respectively. The method equations were solved using Phoneix 150 software package operated under Windows XP (Surface Electro Optics, Korea). 


\subsection{Mechanical characterization}

Mechanical properties of $\mathrm{p}$ (HEMA-GMA), $\mathrm{p}$ (HEMA-GMA)-OH, p(HEMA-GMA)-A, p(HEMA-GMA)-GA, and p(HEMA-GMA)-GA-Phe films were determined from dog-bone shapes (20-mm span length, 3-mm width, and $450 \mu \mathrm{m}$ thickness) cut from the hydrogel films samples. The tensile and elongation breaking experiments were studied with a Lloyd (Fareham Hampshire, England) LS 500 mechanical testing machine at room temperature. The curves of force as a function of deformation $(\mathrm{mm})$ were automatically recorded by the software. The tensile modulus $(\mathrm{kPa})$ and elongation at break were calculated at an extension rate of $2 \mathrm{~mm} / \mathrm{min}(\mathrm{n}=4)$.

\subsection{Platelet adhesion studies on the modified $p(H E M A-G M A)$ based films}

For platelet adhesion studies, modified p(HEMA-GMA) based films were incubated in PBS ( $\mathrm{pH} 7.4$ ) for $2 \mathrm{~h}$. Fresh human blood was obtained from healthy donors. Platelet rich plasma (PRP) was prepared by centrifugation of the fresh blood (anticoagulated with citrate) at $2500 \mathrm{rpm}$ at $4{ }^{\circ} \mathrm{C}$ for $5 \mathrm{~min}$. The modified p(HEMA-GMA) based samples were laid flat in a sterile glass dishes, and were incubated in PRP $(3.0 \mathrm{~mL})$ at $37^{\circ} \mathrm{C}$ for $1 \mathrm{~h}$. After this period, the modified $\mathrm{p}$ (HEMA-GMA) based were gently washed with physiological buffer solution (PBS) to remove non-adhering platelets. The fixing of adhering platelets was performed with $2.0 \%$ glutaraldehyde in PBS buffer at room temperature for $4 \mathrm{~h}$. The composite hydrogel was then washed with PBS buffer, stained with eosin-methylene blue (Wrigth's stain) and examined in an optical microscope (Nikon, Japan). The platelet counts in PRP samples were also carried out before and after incubation period of the modified $\mathrm{p}$ (HEMA-GMA) based films were determined using an optical microscope. The same procedure was used for platelet adhesion studies with all the modified $\mathrm{p}$ (HEMA-GMA) based films after contacting with fibrinogen. The modified p(HEMA-GMA) based films were incubated for $18 \mathrm{~h}$ in fibrinogen solution ( $0.5 \mathrm{mg}$ fibrinogen in PBS) and contacted with platelet rich plasma as described above.

\subsection{Isolation and culture of MSCs on hydrogel films}

MSCs were obtained from female, nine-week-old, 280-300 g Sprague-Dawley rats. The animals were kept in the animal holding facility of the Department of Molecular Biology and Genetics at Bilkent University under controlled conditions at $22{ }^{\circ} \mathrm{C}$ with $12 \mathrm{~h}$ light and $12 \mathrm{~h}$ dark cycles. They were provided with unlimited access of food and water. Our experimental protocol was approved by the Animal Ethics Committee of Bilkent University (BILHADYEK).

After the rats were sacrificed by cervical dislocation, a heterogeneous bone marrow cell population was collected from the femurs and tibias by flushing with a $5 \mathrm{~mL}$ syringe containing 10\% FBS (HyClone, Logan, USA) in DMEM (HyClone). The hydrogel films were placed in 12 well plates and sterilized by exposing short wave UV light for $15 \mathrm{~min}$. Cells isolated from bone marrow were seeded directly on the hydrogel samples and cultured in MesenCult medium (StemCell Technologies, Vancouver, Canada) with a supplement (20\%, w/v; StemCell Technologies) and a penicillin-streptomycin solution ( $1 \%, \mathrm{w} / \mathrm{v}$; HyClone). The plates were incubated under $\mathrm{CO}_{2}$ atmosphere $(5 \%)$ at $37{ }^{\circ} \mathrm{C}$. After $24 \mathrm{~h}$ incubation period, the cells culture medium was changed with fresh one, and the nonadherent cells were removed. During 14 day incubation period, the culture medium was replaced every 3 days after washing with sterile physiological buffer solution.

\subsection{Characterization of MSCS}

At the 14th day of the culture, MSCs were trypsinized and total RNA was purified with RNeasy Mini Kit (Qiagen, Hilden, Germany) with additional DNase treatment $2 \mu \mathrm{g}$ of total RNA was reverse-transcriptased by using DyNAmo cDNA synthesis Kit (Finnzymes, Espoo, Finland) according to the manufacturer's protocol. PCR was performed for mesenchymal (CD90, CD71 and CD29) and hematopoietic (CD34 and CD45) markers with Taq Polymerase (Finnzymes). Initial denaturation step was carried out at $95{ }^{\circ} \mathrm{C}$ for $5 \mathrm{~min}$, followed by 30 (for CD90 and CD34), 35 (for CD 71), 26 (for CD29 and CD45) and 23 (for Gapdh) cycles of denaturation for $30 \mathrm{~s}$ for all genes at $94{ }^{\circ} \mathrm{C}$, annealing for $30 \mathrm{~s}$ at $55{ }^{\circ} \mathrm{C}$ (for CD90, CD34 and Gapdh), $60 \mathrm{~s}$ at $66{ }^{\circ} \mathrm{C}$ (for CD71) and $30 \mathrm{~s}$ at $60{ }^{\circ} \mathrm{C}$ (for $\mathrm{CD} 29$ and $\mathrm{CD} 45$ ), followed by extension for $30 \mathrm{~s}$ (for CD90, CD34, CD29, CD45 and Gapdh) and $45 \mathrm{~s}$ (for CD71) at $72{ }^{\circ} \mathrm{C}$. A final extension at $72{ }^{\circ} \mathrm{C}$ for 5 min was applied to all the reactions. Primers and PCR conditions used for cDNA amplifications were listed in Supplementary Table 1A and 1B, respectively.

\subsection{Methylthiazol tetrazolium (MTT) assay}

The viability of the MCS were assessed by using MTT (3-(4,5Dimethylthiazol-2-yl)-2,5-diphenyltetrazoliumbromide) assay as first described by Mosmann [34]. Prior to cell seeding, all the tested modified $\mathrm{p}$ (HEMA-GMA) based films were sterilized in ethyl alcohol and washed with sterile physiological buffer solution. About $10^{5}$ MSC were seeded in 96-well plates and the assay was performed according to the manufacturer's protocol (Roche). MSCs which were cultured on plastic culture plate alone without hydrogel was designated as control group. Briefly, $10 \mu \mathrm{L}$ of the MTT labeling reagent with a final concentration of $0.5 \mathrm{mg} / \mathrm{mL}$ was added to each well and the cells were incubated for $4 \mathrm{~h}$. Then $100 \mu \mathrm{L}$ solubilization solution was added to each well and left at $37{ }^{\circ} \mathrm{C}$ for overnight. Next day, the absorbance of the samples was measured by ELISA reader with the wavelength between 550 and $600 \mathrm{~nm}$. Experiments were carried out in triplicate.

All data are expressed as means $\pm S D$. Data were analyzed by performing paired $t$-test using Office excel integrated $t$-test. A value of $\mathrm{P}<0.05$ was considered to be statistically significant.

\section{Results and Discussion}

\subsection{Synthesis, modification and characterization of the modified p(HEMA-GMA) films}

In the polymer modification technique, glycidylmethacrylate with pendant epoxy groups is a versatile unit for polymer modification, allowing the incorporation of a variety of functional groups (Figs. 2 and 3 ) that act as tethering points for attachment of ligand molecules. In the earlier studies, the pendant epoxy rings of GMA-based brush were modified to $-\mathrm{HSO}_{3}$ groups and the served to non-covalent bind the enzyme Lipase [31]. GMA brush on the poly(styrene-divinyl benzene) polymer was modified with hydrazine to attach specifically the enzyme Invertase [35]. The attachment of the functional groups on the biomaterials; i) determines its chemical functionality, ii) its electrostatic interaction with the target biological molecules, and iii) its surface energy [35-37]. Thus, polymer modification techniques have become a new and general way to functionalize polymers, and their potential applications in the fields of biomedical materials design [38-40]. Previously, we have reported a biocompatible film composed of poly(hydroxyethyl methacrylate-poly(ethyleneglycolmethacrylate)/hydroxypropyl-chitosan for adhesion of rat mesenchymal stem cells using a interpenetrating technique [4]. In the present work, a bioactive film based on poly(hydroxyethyl methacrylateglycidylmethacrylate) was investigated for modification. The synthetic pathway to the $\mathrm{p}$ (HEMA-GMA) films copolymer was as shown in Fig. 2. Thirteen kinds of functional groups were created on the $\mathrm{p}$ (HEMA-GMA) film by reactions of the epoxy groups of the glycidylmethacrylate unit with a series of pendant $-\mathrm{NH}_{2}$ group containing molecules. The $-\mathrm{NH}_{2}$ group of the molecules served as anchor binding site for modification of the film via direct epoxy ring opening reaction. The ligands substituted on the films are $-\mathrm{NH}_{2}$ groups 


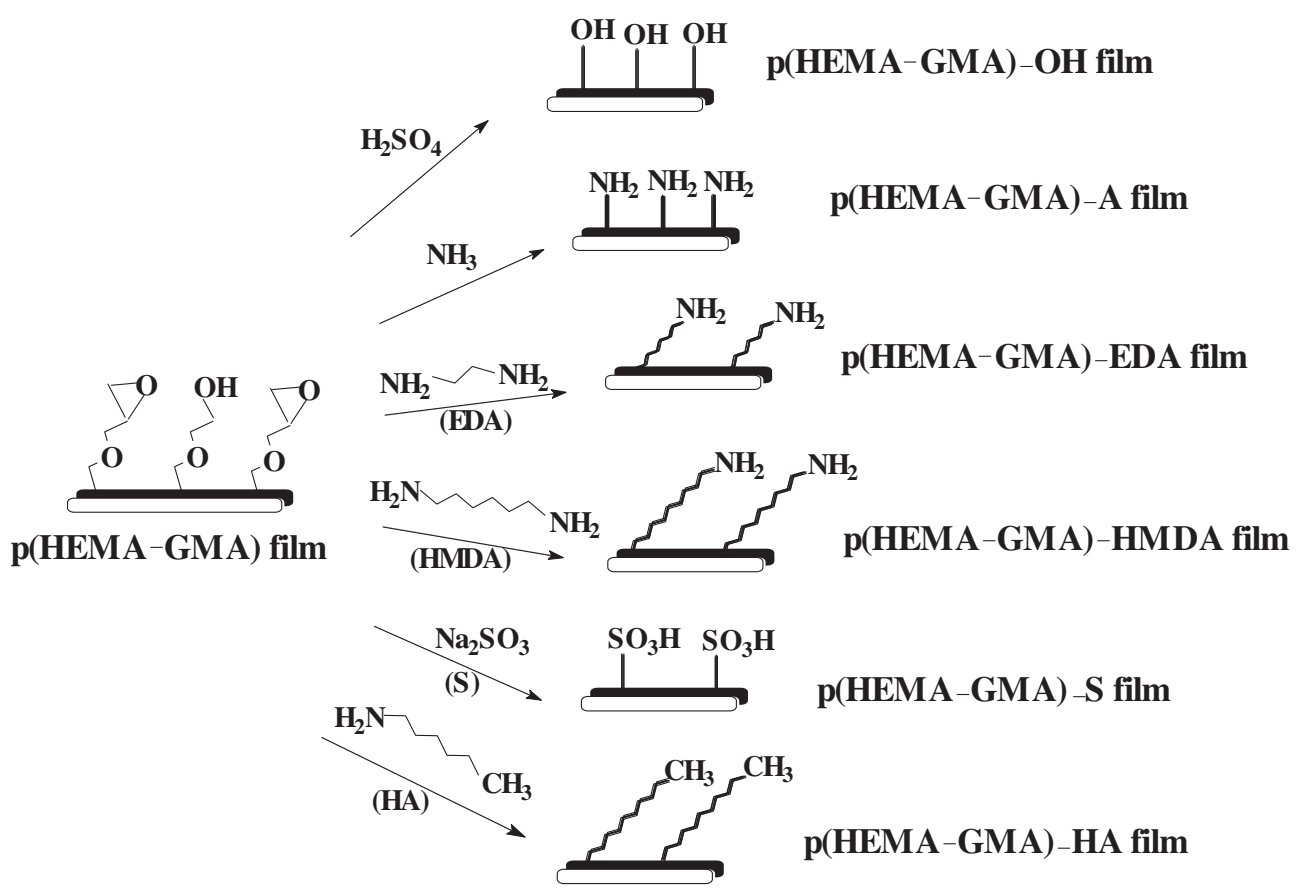

Fig. 2. Direct modification of p(HEMA-GMA) films surface.

(using different chain lengths; ammonia, EDA, and HMDA) $-\mathrm{CH}_{3}$ groups (hexylamine), $-\mathrm{SO}_{3} \mathrm{H}$ (using $\mathrm{Na}_{2} \mathrm{SO}_{4}$ ), aromatic groups substituted with $-\mathrm{OH}$ and $-\mathrm{COOH}$ (i.e., hydroxyl aniline, and amino benzoic acid), and five amino acids (i.e., L-histidine, L-arginine, L-phenylalanine, L-glutamic acid and L-tryptophan), and - $\mathrm{OH}$ group (obtained direct acid hydrolysis of epoxy groups). All these modified films were compared based on their effects on the adhesion and living of rat mesenchymal stem cells (MSCs).

The amount of available epoxy groups on the p(HEMA-GMA) film was determined by $\mathrm{HCl}$-pyridine method and was found to be

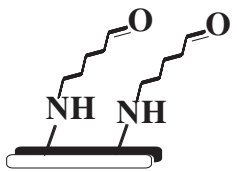

p(HEMA-GMA)-GA film
Ligand<smiles>Nc1ccc(O)cc1</smiles>

HANI

(4-hydroxyaniline)

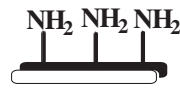

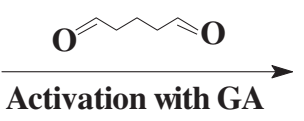

Activation with GA

Ligands:

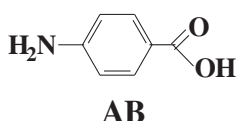

(4-aminobenzoic acid)<smiles>NC(Cc1cnc2ccccc2n1)C(=O)O</smiles>

(L-tryptophan)

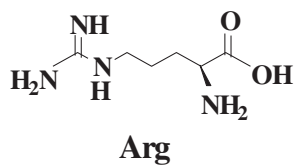

(L-arginine)<smiles>NC(Cc1ccccc1)C(=O)O</smiles>

(L-phenylalanine)<smiles>NC(CCC(=O)O)c1c[nH]cn1</smiles>

His

(L-histidine)<smiles>NC(CCC(=O)O)C(=O)O</smiles>

(L-glutamic acid) 
$3.82 \mathrm{mmol} / \mathrm{g}$ polymers. The amino group contents of the $\mathrm{p}$ (HEMAGMA)-A, p(HEMA-GMA)-EDA and p(HEMA-GMA)-HMDA films were found to be $2.07,1.48$ and $1.36 \mathrm{mmol} / \mathrm{g}$, respectively. The epoxy groups of the film were modified into sulfonic groups using $\mathrm{Na}_{2} \mathrm{SO}_{3}$ in alcohols/water mixture, and the sulfonic group content of the modified film was determined as $2.19 \mathrm{mmol} / \mathrm{g}$ film from the potentiometric titration. The amount of substituted hexylamine ( $\mathrm{p}$ (HEMA-GMA)-HA), 4-aminobenzoic acid ( $\mathrm{p}$ (HEMA-GMA)-GA-AB) and 4-hydroxyaniline ( $\mathrm{p}$ (HEMA-GMA)-GA-HANI) contents of the films were found to be $0.98,0.375$ and $0.384 \mathrm{mmol} / \mathrm{g}$ polymer. The amount of immobilized L-arginine ( $p$ (HEMA-GMA)-GA-Arg), L-histidine ( $\mathrm{p}$ (HEMA-GMA)GA-His), L-glutamic acid (p(HEMA-GMA)-GA-Glu), L-tryptophan ( $\mathrm{p}$ (HEMA-GMA)-GA-Trp) and L-phenylalanine ( (HEMA-GMA)GA-Phe), were found to be $0.448,0.403,0.397,0.416$ and 0.421 , $\mathrm{mmol} / \mathrm{g}$ polymer, respectively. The thickness of the wet films was about $450 \mu \mathrm{m}$. The base film (i.e., p(HEMA-GMA)-OH) density was measured to be $1.19 \mathrm{~g} / \mathrm{cm}^{3}$. The FTIR studies were presented as supplementary data (Supplementary Table 2).

Swelling behavior and structural stability of biomaterials are critical for their practical use in tissue engineering. Swelling behavior of a scaffold may depend on the $\mathrm{pH}$ value of the implantation site. Therefore, the swelling behaviors of the modified p(HEMA-GMA) based films were determined at room temperature at three different $\mathrm{pH}$ values by gravimetric method. The equilibrium water content of the $\mathrm{p}$ (HEMA-GMA)-OH was found to be at $45 \%, 77 \%$ and $98 \%$ at $\mathrm{pH}$ 2.0, 7.4, and 9.0, respectively (Fig. 4). There were no significant differences in the swelling of all the modified hydrogel at the tested $\mathrm{pH}$ values.

\subsection{Evaluation of contact angle measurements and surface energy} parameters of all the modified $p$ (HEMA-GMA) based film

The contact angle measurements data used to evaluate the relative hydrophilicity and hydrophobicity of the modified surface in contact with water, glycerol and diiodomethane. The water contact angle values of the test liquids were measured by putting a sessile drop of test liquid on the surface of the films [39-42]. Each modified p(HEMA-GMA) films surface has different functional groups such as $-\mathrm{OH},-\mathrm{NH}_{2},-\mathrm{NH}-$, $-\mathrm{SO}_{3} \mathrm{H},-\mathrm{COOH},-\mathrm{CH}_{3}$ and aromatic rings for ionic, polar and hydrophobic interaction with proteins and cells. These functional groups are critically important for the development of biomaterials in the field of tissue engineering and regenerative medicine. Therefore, contact angle measurements are used in the characterization of biomaterials surfaces to describe hydrophilicity or to estimate surface free energy. The wettability of a biomaterial surfaces can be examined by comparing the contact angles for water and diiodomethane since these two solvents are often used as reference liquids in analyses of interaction

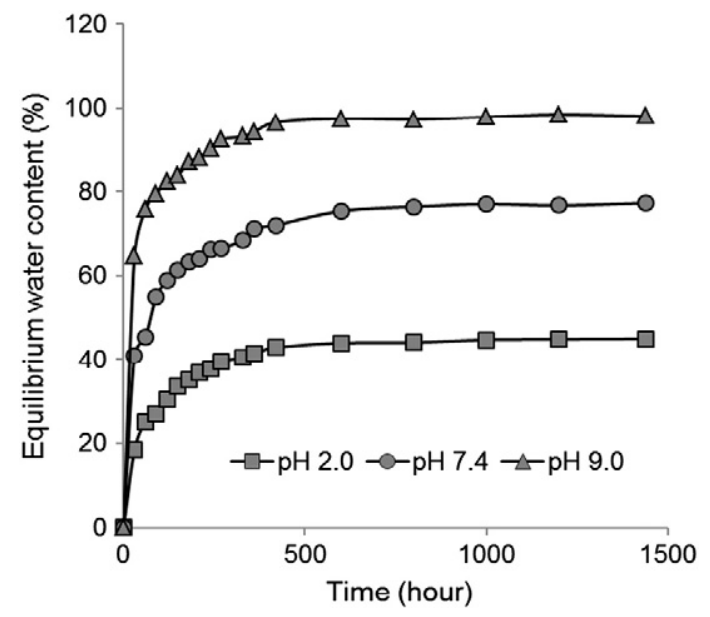

Fig. 4. Water content of the $\mathrm{p}(\mathrm{HEMA}-\mathrm{GMA})-\mathrm{OH}$ film at different $\mathrm{pH}$ values. of polar and apolar solvents with solid surfaces. The results of the contact angle measurements of water, glycerol and diiodomethane on the all the tested modified p(HEMA-GMA) films surfaces are presented in Table 1. These microscopic scale interactions between biomaterials surface and biological molecules can be subdivided into Lifshitz-vander Waals (LW) and Lewis acid-base (AB) contributions and used to predict the free energy of binding and structural organization of the system $[32,33]$. The variation of the wetting force is extremely sensitive to the surface characteristics since it reflects the effect of functional groups on a surface layer thick (less than $10 \mathrm{~A}^{\circ}$ ) and in direct contact with the liquid phase [32,33]. In accordance to the Young equation the smaller the surface tension of the test liquid, the smaller becomes the contact angle measured on the samples surfaces.

All the tested modified p(HEMA-GMA) films gave quite different contact angle values depending on the presence of functional groups. The contact angle measured with a polar liquid is expected to be higher for a hydrophobic surfaces bedwetting and vice versa. As seen from Table 1, the p(HEMA-GMA)-OH film was the most hydrophilic with a contact angle value of 63.2. The contact angles of the $-\mathrm{NH}_{2}$ groups with varying aliphatic chain $\left(-\mathrm{NH}_{2},-\mathrm{NH}-\mathrm{CH}_{2}-\mathrm{CH}_{2}\right.$ $\mathrm{NH}_{2}$, and $\left.-\mathrm{NH}-\left(\mathrm{CH}_{2}\right)_{6}-\mathrm{NH}_{2}\right)$ were 81.4, 83.2 and 85.6, respectively. The $-\mathrm{CH}_{3}$ surface had the highest contact angle value of 105.2 , because of its non-polar nature. As expected, hexylamine, tryptophan and phenylalanine modified films have non-polar surfaces, the remaining modified films have polar surfaces. In addition, the surface chemical feature is not the only factor influencing the surface contact angle. The water contact angle of the surface also decreases with increasing surface roughness when the surface is composed of hydrophilic substances. However, surface roughness is so complicated that it is difficult to develop a general method for the roughness measurement.

The determined overall surface free energy $\left(\gamma^{\mathrm{TOT}}\right)$, calculated using the acid base method of van Oss et al. [32], consisting of the sum of the Lifschitz-van der Waals $\left(\gamma^{\mathrm{LW}}\right)$ and the acid-base components $\left(\gamma^{\mathrm{AB}}\right)$ applies for all the modified films samples at different values (Table 2). The dispersive component made the major contribution to the total surface free energy for all the tested membranes. This resulted in the polar component making approximately a $0.15-5.53 \%$ contribution to the total surface free energy. Hydroxyl, carbonyl, carboxyl, amine groups may increases surface polarity and acidbase reactive sites of the modified films. As seen in the table, p(HEMA-GMA)-OH, p(HEMA-GMA)-S, p(HEMA-GMA)-GA-AB, and $\mathrm{p}$ (HEMA-GMA)-GA-Glu modified films seem to exhibit high "amphoteric" character. The basic parameters $\left(\gamma^{-}\right)$of the $\mathrm{p}$ (HEMA-GMA)-GA-Phe and p(HEMA-GMA)-GA-HANI are larger compared to their acidic parameter $\left(\gamma^{+}\right)$. The relatively high basic $\left(\gamma^{-}\right)$component of the surface energy is caused by the

Table 1

Contact angle values of water, glycerol and diiodomethane on the films with different functional groups carrying.

\begin{tabular}{|c|c|c|c|}
\hline \multirow{2}{*}{$\begin{array}{l}\text { Films with different } \\
\text { functional groups }\end{array}$} & \multicolumn{3}{|c|}{ Test liquids and their surface tensions $\left(\gamma_{1}\right)$} \\
\hline & $\begin{array}{l}\text { Water } \\
\left(\gamma_{1}=71.3\right)\left(\theta^{\circ}\right)\end{array}$ & $\begin{array}{l}\text { Glycerol } \\
\left(\gamma_{1}=64.0\right)\left(\theta^{\circ}\right)\end{array}$ & $\begin{array}{l}\text { Diiodomethane } \\
\left(\gamma_{1}=50.8\right)\left(\theta^{\circ}\right)\end{array}$ \\
\hline $\mathrm{p}(\mathrm{HEMA-GMA)-OH}$ & $63.2 \pm 2.7$ & $66.9 \pm 1.3$ & $30.6 \pm 0.5$ \\
\hline $\mathrm{p}($ HEMA-GMA)-A & $81.4 \pm 3.6$ & $50.6 \pm 1.5$ & $30.2 \pm 1.1$ \\
\hline $\mathrm{p}(\mathrm{HEMA}-\mathrm{GMA})-\mathrm{EDA}$ & $83.2 \pm 2.4$ & $52.7 \pm 1.0$ & $30.5 \pm 1.5$ \\
\hline $\mathrm{p}$ (HEMA-GMA)-HMDA & $85.6 \pm 3.1$ & $55.8 \pm .0 .9$ & $33.7 \pm 1.4$ \\
\hline $\mathrm{p}($ HEMA-GMA)-S & $67.9 \pm 1.7$ & $66.2 \pm 0.6$ & $23.4 \pm 0.4$ \\
\hline $\mathrm{p}$ (HEMA-GMA)-HA & $105.2 \pm 2.4$ & $90.3 \pm 0.3$ & $57.1 \pm 0.3$ \\
\hline $\mathrm{p}$ (HEMA-GMA)-GA-AB & $70.2 \pm 1.6$ & $69.9 \pm 1.2$ & $19.1 \pm 0.7$ \\
\hline $\mathrm{p}$ (HEMA-GMA)-GA-HANI & $88.9 \pm 1.8$ & $75.8 \pm 2.8$ & $24.8 \pm 1.2$ \\
\hline $\mathrm{p}$ (HEMA-GMA)-GA-Arg & $75.4 \pm 2.4$ & $42.3 \pm 1.1$ & $32.5 \pm 1.3$ \\
\hline $\mathrm{p}$ (HEMA-GMA)-GA-His & $78.2 \pm 2.2$ & $51.7 \pm 0.4$ & $29.9 \pm 0.4$ \\
\hline $\mathrm{p}$ (HEMA-GMA)-GA-Glu & $68.6 \pm 1.1$ & $63.4 \pm 1.1$ & $27.6 \pm 1.2$ \\
\hline $\mathrm{p}$ (HEMA-GMA)-GA-Trp & $95.2 \pm 0.9$ & $87.7 \pm 1.4$ & $33.5 \pm 1.4$ \\
\hline $\mathrm{p}$ (HEMA-GMA)-GA-Phe & $92.4 \pm 0.7$ & $78.7 \pm 0.8$ & $28.5 \pm 1.2$ \\
\hline
\end{tabular}


electron ion pairs of oxygen atoms contained in the copolymer (hydroxyl, carbonyl and carboxyl functionalities), which are effective in Lewis base sites [39-43]. On the other hand, opposite trend was observed for $\mathrm{p}$ (HEMA-GMA)-A p(HEMA-GMA)-EDA, $\mathrm{p}$ (HEMAGMA)-HMDA p(HEMA-GMA)-GA-Arg and p(HEMA-GMA)-GA-His modified films. Thus, all these parameters should be effective in determining the surface energy properties of the modified $\mathrm{p}$ (HEMAGMA) based films when contacted with proteins and cells. This study demonstrated that by incorporation different functional groups on the film surface, the surface hydrophilicity and biocompatibility could be improved. As expected, all the investigated materials exhibit different acid base components $\left(\gamma^{\mathrm{AB}}\right)$ of the surface free energy due to the presence of different functional groups on the surface of the films. As reported earlier, surface wettability is recognized as a critical factor for cell behavior, and cells tend to attach better to hydrophilic surfaces than to hydrophobic surfaces [42]. In order to investigate this effect in our system, we investigated the adhesion behavior of MSCs on the highly hydrophilic composite hydrogel with the different surface energy parameters and polarities.

\subsection{Evaluation of mechanical properties of the non-modified and modified hydrogels}

Mechanical properties of $\mathrm{p}$ (HEMA-GMA), $\mathrm{p}$ (HEMA-GMA)-OH, $\mathrm{p}$ (HEMA-GMA)-A, p(HEMA-GMA)-GA, and p(HEMA-GMA)-GA-Phe films were studied at their equilibrium water content. Tensile and percent elongation results of the tested films were presented in Table 3. These results as a whole indicated that the mechanical properties of the $\mathrm{p}$ (HEMA-GMA) hydrogel films were altered after modification reaction. As seen in Table 3 , decrease in the power of the tensile strength for $\mathrm{p}$ (HEMA-GMA)-OH $(147 \pm 4 \mathrm{kPa})$ and $\mathrm{p}$ (HEMAGMA)-A (133 $\pm 5 \mathrm{kPa})$ were observed compared to non modified $\mathrm{p}$ (HEMA-GMA) $(225 \pm 5 \mathrm{kPa})$ hydrogel film. These decreases could be due to the hydrolysis of epoxy groups of the hydrogel into hydroxyl and amine groups. On the other hand, an increase in the elongation percentage was observed $\mathrm{p}$ (HEMA-GMA)-OH $(147 \pm 4 \mathrm{kPa})$ and $\mathrm{p}(\mathrm{HEMA}-\mathrm{GMA})-\mathrm{A}$ compared to non-modified hydrogel film. The amine groups $\mathrm{p}$ (HEMA-GMA)-A hydrogel films was reacted with glutaraldehyde in order to attachment of various ligands. The mechanical properties including tensile modulus and elongation percentage of the p(HEMA-GMA)-GA films were changed after glutaraldehyde cross-linking (Table 3 ). The $\mathrm{p}$ (HEMA-GMA)-GA-Phe film was exemplified for ligand modified films and tensile modulus and elongation percentage were closer to $\mathrm{p}$ (HEMA-GMA)-GA films (Table 3 ).

Table 2

Surface free energy parameters $(\mathrm{mN} / \mathrm{m})$ of the films with different functional groups carrying according to the van Oss et al. method.

\begin{tabular}{lllllr}
\hline $\begin{array}{l}\text { Films with different } \\
\text { functional groups }\end{array}$ & $\begin{array}{l}\gamma^{\text {Total }} \\
{[\mathrm{mN} / \mathrm{m}]}\end{array}$ & $\begin{array}{l}\gamma^{\mathrm{d}} \\
{[\mathrm{mN} / \mathrm{m}]}\end{array}$ & $\begin{array}{l}\gamma^{\mathrm{p}} \\
{[\mathrm{mN} / \mathrm{m}]}\end{array}$ & $\begin{array}{l}\gamma^{+} \\
{[\mathrm{mN} / \mathrm{m}]}\end{array}$ & $\begin{array}{l}\gamma^{-} \\
{[\mathrm{mN} / \mathrm{m}]}\end{array}$ \\
\hline p(HEMA-GMA)-OH & $49.37 \pm 1.52$ & 43.97 & 5.40 & 0.31 & 23.82 \\
p(HEMA-GMA)-A & $45.92 \pm 2.73$ & 44.14 & 1.78 & 2.49 & 0.32 \\
p(HEMA-GMA)-EDA & $45.11 \pm 1.74$ & 44.01 & 1.10 & 2.49 & 0.12 \\
p(HEMA-GMA)-HMDA & $44.07 \pm 1.81$ & 42.62 & 1.45 & 1.89 & 0.28 \\
p(HEMA-GMA)-S & $50.30 \pm 0.92$ & 45.7 & 3.60 & 0.12 & 16.37 \\
p(HEMA-GMA)-HA & $30.35 \pm 1.01$ & 30.24 & 0.15 & 0.32 & 0.17 \\
p(HEMA-GMA)-GA-AB & $50.24 \pm 1.23$ & 46.71 & 5.53 & 0.47 & 16.15 \\
p(HEMA-GMA)-GA-HANI & $46.31 \pm 1.92$ & 45.26 & 1.05 & 013 & 2.19 \\
p(HEMA-GMA)-GA-Arg & $47.03 \pm 1.63$ & 43.16 & 3.88 & 3.86 & 0.97 \\
p(HEMA-GMA)-GA-His & $47.45 \pm 1.07$ & 44.26 & 3.19 & 1.82 & 1.40 \\
p(HEMA-GMA)-GA-Glu & $45.80 \pm 1.15$ & 45.18 & 0.63 & 0.01 & 13.75 \\
p(HEMA-GMA)-GA-Trp & $45.75 \pm 1.33$ & 42.71 & 3.04 & 1.12 & 2.08 \\
p(HEMA-GMA)-GA-Phe & $49.62 \pm 0.92$ & 48.21 & 1.41 & 0.40 & 1.25 \\
\hline
\end{tabular}

\subsection{Interaction of modified $p(H E M A-G M A)$ films with blood platelets}

Fibrinogen has the property of initiating the adherence of thrombocytes to the surface of a biomaterial. The effect of presence of different groups on the hydrogel films were tested before and after contact with fibrinogen. Table 4 summarizes hematological data obtained from in-vitro platelet adhesion studies with modified p(HEMA-GMA) based films. All the free $-\mathrm{NH}_{2}$ containing materials affect platelet adhesion more than other tested hydrogel films. The results show that the p(HEMA-GMA) based films modified with ammonia, EDA, HMDA and arginine exhibits much higher platelets adhesion (up to $50.3 \%$ platelets loss) compared to all other tested hydrogel films (Table 4) under the same experimental conditions. As expected, a high number platelet adhesion was observed with arginine modified hydrogels. As reported earlier, the guanidinium group of the L-arginine side chain serves as an ion-pairing moiety in several biologically relevant molecular interactions. L-Arginine is also a component of the conserved integrin receptor-binding peptide, and 4 analogues of which have been used to modulate cell adhesion [44]. Cell penetrating agents have also been developed based largely upon a 9 amino acid sequence containing 6 L-arginine residues derived from the HIV-1 Tat protein [45]. The overall action mechanism is still not completely clear, but some studies have associated it to the conformation of the guanidine side group of arginine [46]. Minimum platelets adhesion was observed with hydroxyl groups modified films. The hydroxyl and carboxyl groups of the ligands can be expected to reduce the interaction between blood cells and the film surfaces. As expected, hydroxyl and carboxyl groups containing films showed reduced platelet adhesion compared to the free amino groups modified films. The number of the adherent platelets on differently modified surfaces decreased in the order $\mathrm{p}($ HEMA-GMA)-HMDA $>\mathrm{p}($ HEMA-GMA)-Arg $>$ $\mathrm{p}($ HEMA-GMA)-EDA $>\mathrm{p}($ HEMA-GMA)-A $>$ p (HEMA-GMA)-GA-Phe $>$ $\mathrm{p}$ (HEMA-GMA)-GA-Trp $>$ p (HEMA-GMA)-GA-His $>$ p (HEMA-GMA)-S $>$ $\mathrm{p}($ HEMA-GMA)-GA-HANI $>\mathrm{p}$ (HEMA-GMA)-GA-AB $>\mathrm{p}$ (HEMA-GMA)HA $>p($ HEMA-GMA)-GA-Glu $>$ and $p$ (HEMA-GMA)-OH. As seen in Table 4 the modification of $\mathrm{p}$ (HEMA-GMA) based film with $-\mathrm{OH}$ and $-\mathrm{COOH}$ groups improves its biocompatibility as evaluated in terms of platelet adhesion. On the other hand, the hydrogel film samples, incubated with fibrinogen for $18 \mathrm{~h}$, showed slightly higher platelet adsorption than those of the free fibrinogen containing counterpart (data not shown).

\subsection{Hemolytic activity of hydrogel films}

Hemolysis is an important factor to assess the biocompatibility of a material [8]. Hence, hemolytic assays were performed to examine interaction of modified films with red blood cell membranes by measuring the released hemoglobin. The hemolytic activity of all the modified films was assessed in vitro by using hemolysis tests. The hemolytic activities of the biomaterials with isotonic saline solution are as the blank. As expected complete hemolysis was observed in distilled water which was the positive control but was negligible in physiological saline solution (negative control). Table 4 shows that the modified films have percentage hemolysis values which range from $1.34 \%$ to $4.36 \%$. In the hemolysis test, the maximum hemolysis value was observed with $\mathrm{p}$ (HEMA-GMA)-HMDA films

Table 3

Mechanical properties of the p(HEMA-GMA) modified hydrogel films.

\begin{tabular}{lll}
\hline Hydrogel films & Tensile modulus (kPa) & Elongation (\%) \\
\hline p(HEMA-GMA) & $225 \pm 5$ & $5.3 \pm 0.2$ \\
p(HEMA-GMA)-OH & $147 \pm 4$ & $7.6 \pm 0.3$ \\
p(HEMA-GMA)-A & $133 \pm 5$ & $6.1 \pm 0.2$ \\
p(HEMA-GMA)-GA & $354 \pm 9$ & $3.2 \pm 0.1$ \\
p(HEMA-GMA)-GA-Phe & $347 \pm 8$ & $3.1 \pm 0.2$ \\
\hline
\end{tabular}


Table 4

Platelet adhesion on the modified films and percentage hemolysis values of modified films.

\begin{tabular}{llrl}
\hline Modified films & $\begin{array}{l}\text { Platelet count number } \\
\left(\times 10^{3} / \mathrm{mm}^{3}\right) \text { final count }\end{array}$ & $\begin{array}{l}\text { Platelet } \\
\text { loss }(\%)\end{array}$ & $\begin{array}{l}\text { Hemolysis } \\
(\%)\end{array}$ \\
\hline p(HEMA-GMA)-OH & $367 \pm 07$ & $6.9 \pm 0.2$ & $1.34 \pm 0.15$ \\
p(HEMA-GMA)-A & $215 \pm 11$ & $45.4 \pm 1.1$ & $3.48 \pm 0.02$ \\
p(HEMA-GMA)-EDA & $207 \pm 09$ & $47.5 \pm 1.4$ & $4.05 \pm 0.07$ \\
p(HEMA-GMA)-HMDA & $196 \pm 08$ & $50.3 \pm 1.5$ & $4.36 \pm 0.14$ \\
p(HEMA-GMA)-S & $314 \pm 12$ & $20.3 \pm 0.7$ & $2.13 \pm 0.14$ \\
p(HEMA-GMA)-HA & $338 \pm 13$ & $14.2 \pm 0.8$ & $1.76 \pm 0.13$ \\
p(HEMA-GMA)-GA-AB & $322 \pm 11$ & $18.3 \pm 0.4$ & $1.89 \pm 0.04$ \\
p(HEMA-GMA)-GA-HANI & $317 \pm 06$ & $19.5 \pm 0.7$ & $1.94 \pm 0.03$ \\
p(HEMA-GMA)-GA-Arg & $204 \pm 09$ & $48.2 \pm 0.9$ & $4.13 \pm 0.07$ \\
p(HEMA-GMA)-GA-His & $296 \pm 10$ & $24.9 \pm 0.8$ & $1.97 \pm 0.06$ \\
p(HEMA-GMA)-GA-Glu & $341 \pm 12$ & $13.5 \pm 0.4$ & $1.36 \pm 0.17$ \\
p(HEMA-GMA)-GA-Trp & $295 \pm 09$ & $25.1 \pm 0.7$ & $2.75 \pm 0.11$ \\
p(HEMA-GMA)-GA-Phe & $267 \pm 12$ & $32.2 \pm 1.1$ & $2.56 \pm 0.13$ \\
\hline
\end{tabular}

Initial platelet count $=394 \pm 9 \times 10^{3}$ per $\mathrm{mm}^{3}$ plasma.

(about 4.36\%). On the other hand, p(HEMA-GMA)-OH and p(HEMAGMA)-GA-Glu modification showed low degree of hemolytic activity about $1.34 \%$ and $1.36 \%$, respectively. On the other hand, pendant $-\mathrm{NH}_{2}$ decorated surface is cationic and thus electrostatically interact with several glucoprotein, and other molecules possessing a negative charge. This allows $-\mathrm{NH}_{2}$ to form ionic complexes with many anionic biomolecules such as formation of polymer-lipid complexes between hydrogel surface and cell membrane, which will be create a disruption mechanism. The chemical formulation of the amine groups also seems to play a critical role in the polymer-cell interaction, as evidenced by HMDA modified hydrogels, has a higher amount of hemolytic activity compared to other tested hydrogels formulated with differently amine groups. Palermo and Kuroda [47] prepared methacrylate based copolymer contained primary or tertiary amine groups, or quaternary ammonium groups, and were utilized as the source of cationic charge in each copolymer series. Measurements of the bactericidal and hemolytic activities in buffers of $\mathrm{pH}$ varying from 6 to 8 showed the impact of polymer ionization on biological activity. A decrease in the fraction of amine groups that are cationic caused an enhancement of antimicrobial and hemolytic activity. Thus, the hemolytic activity tests suggest that presence of pendant amino groups increased the hemolytic activity compared to other tested modifications. Autian [48] has reported that up to $5.00 \%$ hemolysis is permissible for biomaterials. As seen in the table, the maximum hemolysis was observed about $4.36 \%$. It may be concluded that all tested modified hydrogels are comparable and can be used as suitable for various biomedical application purpose.

\subsection{Bone marrow derived MSCs grown on hydrogel films}

The functional groups on the biomaterials determine chemical functionality, electrostatic interaction, surface energy, and biological cues of the surface, and therefore, influence cell-biomaterial interaction directly. The poly(hydroxyethyl methacrylate), p(HEMA) based hydrogel is suitable as a biomaterial due to its good mechanical strength, elasticity, and long history of successful application in medicine and it can be easily fabricated in various form. However, it lacks functional groups to which biological molecules can be easily attached as also shown by us [8]. Therefore, pHEMA based hydrogel can be prepared with reactive groups carrying comonomer such as glycidylmethacrylate [31]. The reactive epoxy group carrying $\mathrm{p}(\mathrm{HEMA}-\mathrm{GMA})$ films were modified to induce cell responses, in particular $-\mathrm{NH}_{2},-\mathrm{CH}_{3},-\mathrm{SO}_{3} \mathrm{H}$, aromatic groups substituted $-\mathrm{OH}$ and $-\mathrm{COOH}$, L-histidine, L-arginine, L-phenylalanine, L-glutamic acid, L-tryptophan, have been incorporated onto $\mathrm{p}$ (HEMA-GMA) surface via epoxy groups of the functional polymer without altering its bulk properties. Our purpose was to evaluate the suitability of these biomaterials in MSCs' attachment and maintenance since
MSCs have been shown to have very important roles in regenerative medicine and tissue engineering [4]. Using stem cells as a therapeutic agent has been receiving tremendous interest as it provides opportunities to combat with debilitating diseases. Bone marrow derived MSCs were isolated from rats. Consistent with previous observations by us and others [49-51], the cells were positive for mesenchymal stem cell markers such as CD90, CD71, and CD29, and negative for hematopoietic cell lineage markers such as CD34 and CD45 shown by RT-PCR (Fig. 5A). When mRNA was used as a template as a negative control in order to check possible DNA contamination during isolation, we did not detect any band confirming that there was no contamination (Fig. 5B). After seeding MSCs, we observed their attachment on all modified $\mathrm{p}$ (HEMA-GMA) films (data not shown).

\subsection{MSCs viability on the modified $p$ (HEMA-GMA) based films}

The viability of the MCS were assessed using MTT (3-(4,5dimethylthiazol-2-yl)-2,5-diphenyltetrazoliumbromide) assay as first described by Mosmann [34]. MTT assay is a useful method for the omeasurement of in vitro cytotoxicity, cell adhesion, cell proliferation, and cell number. It is a colorimetric assay which determines viable cell numbers and is based on the conversion by mitochondrial succinate dehydrogenases of the tetrazolium salt, 3-[4,5-dimethylthiazol-2-yl]2,5-diphenyl-2H-tetrazolium bromide (MTT), a water-soluble yellow dye, to a water-insoluble purple formazan product that has been shown to be proportional to the numbers of living cells presented. The tetrazolium ring is cleaved in active mitochondria, so the reaction occurs only in living cells. The MTT assay has been demonstrated as a sensitive, precise, convenient, rapid and economical test method by many studies [52,53]. Therefore, we used MTT assay as a reliable quantitative method to assess the effect of polymeric films on MSCs (Fig. 6). All these tested functional groups naturally present on the surface of living cells. In order to assess the effect of modifications on the polymeric films in MSCs' viability, we divided modifications into three groups by comparing to the control group which did not have any modification at all; i) modified films that lead to increased MSC viability than the control, ii) modified films that lead to the viability rate similar to the control, and iii) modified films that lead to decreased MSC viability compared to the control group. Among them, modifications such as p(HEMA-GMA)-GA-Phe, p(HEMA-GMA)-GA-AB p(HEMA-GMA)-GA-Trp, and p(HEMA-GMA)GA-Glu resulted higher MSC viability than the control group. It should be noted that $\mathrm{p}$ (HEMA-GMA)-GA-AB and p(HEMA-GMA)-GA-Phe modified film displayed significantly stronger adhesion after overnight incubation, compared with all the tested p(HEMA-GMA) based films. The cell numbers on both the $p$ (HEMA-GMA)-GA-AB and $\mathrm{p}$ (HEMA-GMA)-GA-Phe films were about $60 \%$ higher compared to control culture $(\mathrm{P}<0.05)$. These data demonstrated that $\mathrm{p}$ (HEMAGMA)-GA-AB, and p(HEMA-GMA)-GA-Phe could significantly increase cell adhesion and cell number compared with all the other modified films. Another amino acid attached film, p(HEMA-GMA)-GA-His and p(HEMA-GMA)-GA-HANI as well as p(HEMA-GMA)-OH possessed similar cell viability rate to that of control group with a range of $10 \%$ to $25 \%$. Meanwhile the viability rate was found to be lower to that of control when MSCs were cultured on modified polymeric films such as p(HEMA-GMA)-GA-Arg, p(HEMA-GMA)-HA, p(HEMA-GMA)-HMDA $\mathrm{p}$ (HEMA-GMA)-EDA and $\mathrm{p}$ (HEMA-GMA)-A. Among these modifications, cell viability decreased significantly $(\mathrm{P}<005)$ in $\mathrm{p}(\mathrm{HEMA}-\mathrm{GMA})-\mathrm{GA}-\mathrm{S}$ $\mathrm{p}$ (HEMA-GMA)-GA-HMDA $\mathrm{p}$ (HEMA-GMA)-GA-EDA and $\mathrm{p}$ (HEMAGMA)-GA-A (Fig. 6). As shown in Fig. 2, when the chain lengths of the amino groups increased, the cell attachment and living cell number were increased. This observation represents strong experimental evidence that the chain length of incorporated $-\mathrm{NH}_{2}$ is an important factor for cell adhesion and cell growth. As seen from Fig. 5, p(HEMA-GMA) film modified with $-\mathrm{NH}_{2}$ moieties with different chain lengths, resulted in significant decrease in the living MSC compared to all other modified and control substrates. The $-\mathrm{NH}_{2}$ groups contained 

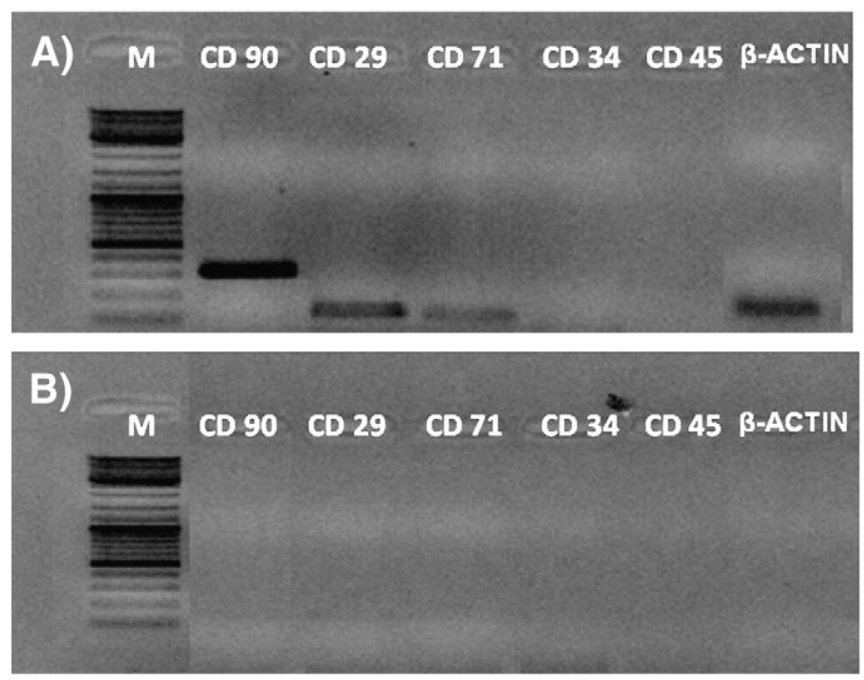

Fig. 5. Characterization of bone marrow-derived mesenchymal stem cells on $\mathrm{p}$ (HEMA-GMA) film modified with $-\mathrm{NH}_{2}$ moieties. A) The expression of the markers of MSCs (CD90, CD29 and CD71) and hematopoietic cells (CD34, CD45). Expression of $\beta$-actin was used as loading control. B) (-) controls of PCR reaction.

surface should provide attractive electrostatic interaction between the positively charged surface and the negatively charged cells. As observed platelet adhesion studied, a high amount of platelet adsorption on $\mathrm{p}$ (HEMA-GMA)-A, p(HEMA-GMA)-EDA, and p(HEMA-GMA)-HMDA were observed than those of the other tested modified surfaces. Thus, the strong interaction of MSC with the amine groups modified hydrogels may inhibit the cell growth, and resulted in a decrease in detected viability activity with MTT test. Finally, the lowest rate was observed on the polymeric formulation of $\mathrm{p}$ (HEMA-GMA)-S suggesting that sulfonic acid group modified hydrogel could cause an inhibitory effect on MSC expansion and viability due to high levels of negatively charged acidic groups. Incorporation of $-\mathrm{CH}_{3}$ (i.e., $\mathrm{p}$ (HEMA-GMA)-HA), and arginine with guanidium groups (i.e., p(HEMA-GMA)-GA-Arg) decreased the viability compared to control group.

Thus, $p$ (HEMA-GMA)-GA-AB, p(HEMA-GMA)-GA-Phe, p(HEMAGMA)-GA-Trp, p(HEMA-GMA)-GA-Glu, p(HEMA-GMA)-OH, p(HEMAGMA)-GA-His and p(HEMA-GMA)-GA-HANI are proven to be suitable

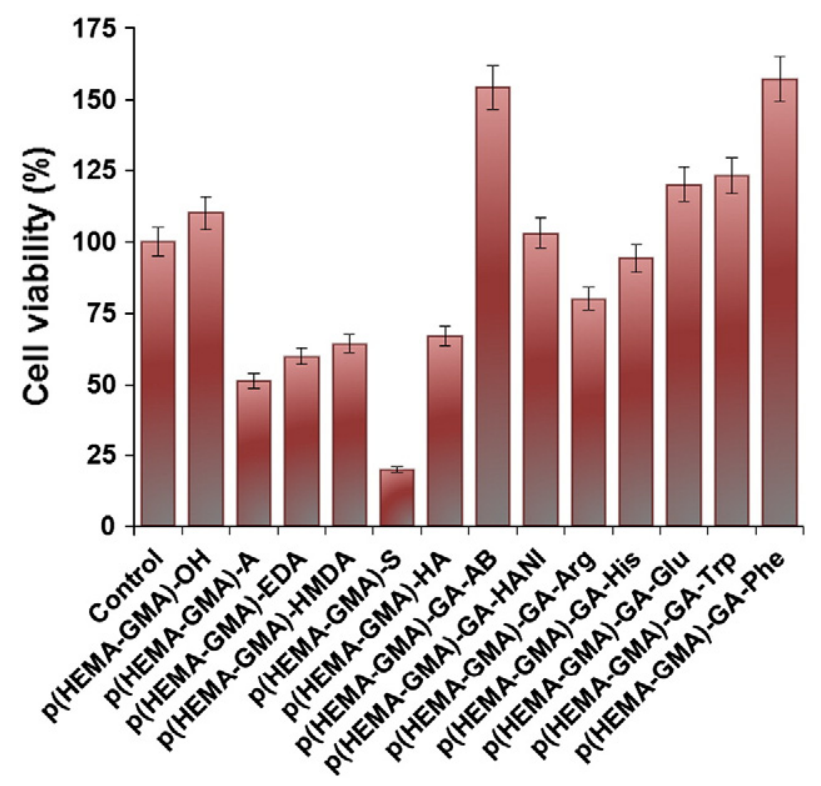

Fig. 6. MTT assay: the difference of percent viability of MSCs on different types functional groups containing films. formulations to use in culturing and expanding MSCs compared to all the other modified $\mathrm{p}$ (HEMA-GMA) based films.

In the literature, it has been discussed that extreme results in the MTT assay (any material inducing a reduction of $>30 \%$ in cell viability (cytotoxicity assay according to ISO 10993-5) is considered toxic) suggests that the tested material is toxic and should be further investigated with other methods [54,55]. It is also tempting to speculate that MSCs' interaction with these modified hydrogels may cause them to increase their potency and may increase their differentiation capacity. This clearly warrants new experiments and their role on differentiation and proliferation is ongoing studies in our laboratory. In addition, some of these modified films may exert toxic effect to the cells or they not allow to diffusion of nutrients and waste product of cells to the medium because of the incorporation of different functional groups, which may be the reason in observation of cells grown in some of these modified films.

\section{Conclusion}

The use of biomaterials and technologies has become one of the leading areas in science and creates a local environment which enables cells to promote their proliferation and differentiation. Several established methods are presently available for in vitro isolation and differentiation of MSCs from bone marrow. In this study, we aimed to examine the effect of different groups on the adhesion and survival of the rat bone marrow derived MSCs. Novel composite hydrogel film based on p(HEMA-GMA) was prepared by UV-initiated photo-polymerization, different functional groups on the film were incorporated to prepare and characterize hydrogel films for mesenchymal stem cells which represent one of the most accessible sources of stem cells for therapeutic use today. The polarities and the surface free energies of the hydrogels were determined by contact angle measurements. Both water contact angle and water content measurements demonstrated that the surface hydrophilicity of the materials was increased by introduction $-\mathrm{OH},-\mathrm{COOH},-\mathrm{NH}_{2}$ groups on the copolymer surfaces. The platelet adhesion studies demonstrated that the introduction of $-\mathrm{NH}_{2}$ groups onto p(HEMA-GMA) surface significantly increased the platelet adhesion capacities of the films by improving fouling properties to cell adhesion. Finally, our results showed that aromatic groups substituted- $\mathrm{OH}$ and $-\mathrm{COOH}$ anchor molecules, L-histidine L-phenyl-alanine, L-glutamic acid, and L-tryptophan promoted MSC adhesion and survival compared to all other modified and control culture. In addition, amine groups carrying surfaces with different spacer length, and $-\mathrm{SO}_{3} \mathrm{H}$ modified surfaces showed an inhibitory effect on MSCs. These modifications resulted up to $80 \%$ inhibition on the survival of MSCs. Our results revealed that the modified biomaterial surfaces would be a good choice for the growth and maintenance of MSCs which may be useful tool for further applications in tissue engineering.

\section{Appendix A. Supplementary data}

Supplementary data to this article can be found online at http:// dx.doi.org/10.1016/j.msec.2012.11.004.

\section{References}

[1] A. Guiseppi-Elie, Biomaterials 31 (2010) 2701.

[2] E. Bieberich, Guiseppi-Elie, Biosens. Bioelectron. 19 (2004) 923.

[3] A.J. Dulgar-Tulloch, R. Bizios, R.W. Siegel, J. Biomed. Mater. Res. A 90 (2009) 586.

[4] G. Bayramoglu, K.C. Akcali, S. Gultekin, E. Bengu, M.Y. Arica, Macromol. Res. 19 (2011) 385 .

[5] M.Y. Arica, D. Tuglu, M.M. Basar, D. Kilic, G. Bayramoglu, E. Batislam, J. Biomed. Mater. Res. B 86B (2008) 18.

[6] G. Bayramoglu, E. Batislam, M.Y. Arica, J. Appl. Polym. Sci. 112 (2008) 1012.

[7] E. De Giglio, D. Cafagna, M.M. Giangregorio, M. Domingos, M. Mattioli-Belmont, S. Cometa, J. Bioactive Compatible Polym. 26 (2011) 420.

[8] M.Y. Arica, G. Bayramoglu, B. Arica, K. Ito, Y. Yagci, Macromol. Biosci. 5 (2005) 983.

[9] M.J. Ernsting, G.C. Bonin, M. Yang, R.S. Labow, J.P. Santerre, Biomaterials 26 (2005) 6536. 
[10] J.M. Goddard, J.H. Hotchkiss, Prog. Polym. Sci. 32 (2008) 698

[11] S. Abraham, S. Brahim, K. Ishihara, A. Guiseppi-Elie, Biomaterials 26 (2008) 4767.

[12] A.K. Shakya, H. Sami, A. Srivastava, A. Kumar, Prog. Polym. Sci. 35 (2010) 459.

[13] A.J. Friedenstein, R.K. Chailakhjan, K.S. Lalykina, Cell Tissue Kinet. 3 (1970) 393.

[14] M.L. da Silva, A.I. Caplan, N.B. Nardi, Stem Cells 26 (2008) 2287.

[15] Z. Tokcaer-Keskin, A.R. Akar, F. Ayaloglu-Butun, Can. J. Physiol. Pharmacol. 87 (2009) 143.

[16] A.J. Nauta, W.E. Fibbe, Blood 15 (2010) 3499.

[17] P. Bai, X. Cao, Y. Zhang, Z. Yin, Q. Wei, C.J. Zhao, J. Biomater. Sci. Polym. Ed. 21 (2010) 1559.

[18] E. Sykova, P. Jendelova, L. Urdzikova, P. Lensy, A. Hejcl, Cell. Mol. Neurobiol. 26 (2006) 1111.

[19] A.K. Bajpai, Polym. Int. 56 (2006) 231.

[20] W.W. Thein-Han, R.D.K. Misra Acta, Biomaterialia 5 (2009) 1182.

[21] M.E. Bernardo, F. Locatelli, W.E. Fibbe, Ann. N. Y. Acad. Sci. 1176 (2009) 101.

[22] X. Fan, T. Liu, Y. Liu, X. Ma, Z. Cui, Biotechnol. Prog. 25 (2009) 499.

[23] A.J. Dulgar-Tulloch, R. Bizios, R.W. Siegel Material, Sci. Eng. C 31 (2011) 357.

[24] G. Bayramoglu, M. Yılmaz, E. Batislam, M.Y. Arica, J. Appl. Polym. Sci. 109 (2000) 749.

[25] G. Bayramoglu, M.Y. Arica, Bioprocess Biosyst. Eng. 35 (2012) 423.

[26] I. Gursel, C. Balcik, Y. Arica, O. Akkus, N. Akkas, Biomaterials 19 (1998) 1137.

[27] A.J. Engler, S. Sen, H.L. Sweeney, D.E. Discher, Cell 126 (2006) 677.

[28] D.E. Discher, P. Janmey, Y.-L. Wang, Science 310 (2005) 1139.

[29] F. Rehfeldt, A.E.X. Brown, M. Raab, S.S. Cai, A.L. Zajac, A. Zemel, D.E. Discher, Integr. Biol. 4 (2012) 422

[30] F. Rehfeldt, A.J. Engler, A. Eckhardt, F. Ahmed, D.E. Discher, Adv. Drug Deliv. Rev. 59 (2007) 1329.

[31] M.Y. Arica, H. Soydogan, G. Bayramoglu, Bioprocess Biosyst. Eng. 33 (2010) 227.

[32] C.J. Van Oss, R.J. Good, M.K.J. Chaudhury, Colloid Interface Sci. 111 (1986) 378.

[33] C.J. van Oss, J. Mol. Recognit. 16 (2003) 177.

[34] T. Mosmann, J. Immunol. Methods 65 (1983) 55

[35] E. Yavuz, G. Bayramoglu, B.F. Senkal, M.Y. Arica, J. Chromatogr. B 877 (2009) 1479.
[36] F.J. Xu, K.G. Neoh, E.T. Kang, Prog. Polym. Sci. 34 (2009) 719.

[37] A.P. Khandwekar, M.J. Doble, J. Mater. Sci. Mater. Med. 22 (2011) 1231.

[38] M. Homocianu, D. Macocinschi, M.J. Butnaru, J. Macromol. Sci. B Phys. 50 (2011) 720

[39] S. Liao, C.K. Chan, S. Ramakrishna, Mater. Sci. Eng. C 28 (2008) 1189.

[40] M. Lupu, D. Macocinschi, G. Ioanid, M. Butnaru, S. Ioan, Polym. Int. 56 (2007) 389.

[41] S.P. Thomas, S. Thomas, R. Abraham, S. Bandyopadhyay, Polym. Lett. 7 (2008) 528.

[42] G. Bayramoglu, M. Yilmaz, M.Y. Arica, Colloids Surf. A 243 (2008) 11

[43] G. Bayramoglu, M.Y. Arica, Int. J. Biol. Macromol. 37 (2005) 249.

[44] U. Hersel, C. Dahmen, H. Kessler, Biomaterials 24 (2003) 4385.

45] S. Ruben, A. Perkins, R. Purcell, K. Joung, R. Sia, R. Burghoff, W.A. Haseltine, C.A Rosen, J. Virol. 63 (1989) 1.

[46] F. Fenili, A. Manfredi, E. Ranucci, P. Ferruti, Int. J. Polym. Sci. (2011) 20 (Article ID 161749).

[47] E.F. Palermo, K. Kuroda, Biomacromolecules 10 (2009) 1416

[48] J. Autian, in: R.L. Kronenthal, Z. Oser, E. Martin (Eds.), Polymer Science and Technology, Polymers in Medicine and Surgery, 8, Plenum Press, New York 1975, p. 181.

[49] Z. Tokcaer-Keskin, Z.G. Dikmen, F. Ayaloglu-Butun, S. Gultekin, S.M. Gryaznov, K.C. Akcali, Stem Cell Rev. 6 (2010) 224.

[50] A.A. Mangi, N. Noiseux, D. Kong, H. He, M. Rezvani, J.S. Ingwall, V.J. Dzau, Nat Med. 9 (2003) 1195.

[51] M.F. Pittenger, A.M. Mackay, S.C. Beck, R.K. Jaiswal, R. Douglas, J.D. Mosca, M.A Moorman, D.W. Simonetti, S. Craig, D.R. Marshak, Science 284 (1999) 143.

[52] G. Ciofani, S. Danti, D. D'Alessandro, S. Moscato, A. Menciassi, Biochem. Biophys. Res. Commun. 394 (2010) 405

[53] G. Zund, Q. Ye, S.P. Hoerstrup, A. Schoeberlein, A.C. Schmid, J. Grunenfelder, P. Vogt, M. Turina, Eur. J. Cardiothorac. Surg. 15 (1999) 519.

[54] B.R. Twaites, C.H. Alarcon, M. Lavigne, A. Saulnier, S. Pennadam, D. Cunliffe, D.C Gorecki, C.J. Alexander, J. Control. Release 108 (2005) 472.

[55] ISO 10993 part 5: Tests for in vitro cytotoxicity". 